\title{
AN ANALYSIS OF BRAND AWARENESS INFLUENCE ON PURCHASE INTENTION IN BANDAR LAMPUNG CITY'S ONLINE TRANPORTATION SERVICE (Study on Y Generation Consumers)
}

\author{
Dorothy Rouly Haratua Pandjaitan ${ }^{1}$ \\ Faculty of Economy and Business, Lampung University \\ Bandar Lampung, Indonesia
}

\begin{abstract}
A brand has a value that is delivered to the consumer. Services are everything that the consumers want to use and enjoy. In the transportation service industry, the best service is to create value services that can attract consumers to use the service. The object of ths study is consumers from the $Y$ Generation. The $Y$ Generation is a society group whose members are 26 years old and above, where the main two factors in relation to their needs is comfort and security. The Go-Jek brand is a well-known transportation services brand throughout Indonesia. The conclusion of this study is the high brand value of Go-Jek brand is increases the intention of using Gojek services especially from the Y Generation consumers. The implication of this study is that Go-Jek Company must utilise $Y$ Generation consumer needs such as comfort and an alternative path for travelling so then the consumer can arrive at the destination faster.
\end{abstract}

Keywords: Consumer Behaviour, Brand Awareness, Brand, Purchase Intention, Generation $Y$.

${ }^{1}$ dorothy rouly@yahoo.com; Faculty of Economy and Business, Lampung University 


\section{INTRODUCTION}

Indonesia is a developing country with a high level of productivity, so society needs to utilise the multiple transportation alternatives available to support their daily activity. The Indonesian territory socio-demographic condition has an influence on transportation performance. There is a population density of 262 million living in Indonesia (GetCraft, 2018). They have a significant influence on the transportation performance that serving the society needs. In the urban area, the population density implies the high rivalry of transportation service providers (Susantoro \& Parikesit, 2004:14). The complexity of public transportation is not only because of issues for the government and the provider, but also for society. The scarceity of comfortability, safety and affordability of public transportation hinders society in their daily mobility (Aminah, 2017).

Online transportation is one of the newest service innovations available in m-commerce. Online transportation services or ride-sharing is an individual transportation service where a customer can order a ride (taxicar, taxibike, etc.) through a mobile application and the driver can respond to the order through the app (Silalahi et al, 2017). More than five years ago, if an individual needed transportation services, such as taxi, then they must have made a call first to book a taxi, and then head to the taxicar or taxibike pool to get a taxi ride. Now, we just press on our smartphone screen, and the online transportation ride will directly come to the doorstep, ready to take us to our destination without any hassle to do with charges and fee negotiation. Nowadays, the majority of society is switching to a more organised and modern transportation method such as online transportation. For example Go-Jek, the Indonesian online transportation app and company for taxibikes (Mahargiono, Bambang, and Cahyono. 2017).

There are already a number of popular online transportation services in Europe and USA, such as Lyft, UberX, Sidecar, and Carpool. Meanwhile in Indonesia, popular online transportation services are GO-JEK, Grab, Uber, Bajaj App, Transjek, Wheel Line, Bangjek, Ojek Syar'I, and Blue-Jek (okezone.com, 2015; Silalahi et al, 2017). GOJEK, Grab, and Uber are the ones who hold the largest market share and tightly compete with each other (Pratama, 2016; cited in Silalahi et al, 2017). Online taxibikes answer the society anxiety over security assurances in public transportation, because the 
online transportation company has an organised data-based application. This lets society know about the driver's identity. The online transportation company places user safety as their top priority, and online transportation services can be acquired from Go-Jek. The user can therefore be assured about the provider offering both safety and acountability (Ekawati, 2014).

\section{About Go-Jek}

Go-Jek was established because of price transparency issues, safety issues and uncertainty issues such as vehicle drivers, helmet availability issues and various other problems experienced by consumers. Go-Jek appears to provide solutions for problems that not only come from the consumers, but also from conventional taxibike drivers. Go-Jek management analysed that the waiting time at the taxibike pool should be more productive. If the taxibike driver is using a conventional system such as waiting in the pool for manual pick up orders, it will not be productive. In fact, there could be a time when the pool is empty while they are picking up orders and Go-Jek is present to solve this problem (Nadhilah, Siti, 2017).

Starting in 2010 as a taxibike transportation company by phone call, Go-Jek has now grown to become a leading on-demand mobile platform and application that provides a full range of services including transportation, logistics, payment, food delivery and other various on-demand services. Go-Jek is a social-technology enterprise that aims to improve the welfare of workers in various informal sectors in Indonesia. The activities of Go-Jek are based on 3 basic values of speed, innovation, and social impact. The drivers of Go-Jek say that their revenue has increased since joining as a partner because they can gain access to more customers through the Go-Jek app. They also receive health and accident benefits, access to financial and insurance advisors, affordable auto installments, and other facilities.

Go-Jek has operated in 50 cities in Indonesia, such as Jakarta, Bandung, Surabaya, Bali, Makassar, Medan, Palembang, Semarang, Yogyakarta, Balikpapan, Malang, Solo, Manado, Samarinda, Batam, Sidoarjo, Gresik, Pekanbaru, Jambi, Sukabumi, Bandar Lampung, Padang, Pontianak, Banjarmasin, Mataram, Kediri, Probolinggo, Pekalongan, Karawang, Madiun, Magelang, Tasikmalaya, Belitung, Banyuwangi, Salatiga, Garut, Bukittinggi, Pasuruan, Tegal, Sumedang, Banda Aceh, Mojokerto, Cilacap, Purwakarta, Pematang Siantar, and Madura and is developing in other cities in the coming year. 
Bandar Lampung, which is the capital city of Lampung province itself, became one of the cities where Go-Jek operates in as of March 2017.

Taxibike drivers are recruited and trained professionally, and are equipped with jackets, helmets and smartphones that function to allow them to see reservations and to calculate prices by travel distance. People in Bandar Lampung are very pleased with online transportation such as Go-Jek, because they can easily book reservations using an app through their smartphones, with affordable prices and better safety. Online taxibikes nowadays present a variety of services that exist in their applications, so people are very satisfied because Go-Jek taxibike not only to takes them to their destination, but they can also handle food and items delivery.

\section{About the Y Generation}

Millennials (also known as the $\mathrm{Y}$ Generation) are a demographic group after the $\mathrm{X}$ Generation (X-Gen). There is no definite time limit for the start and end of this group. Experts and researchers usually use the early 1980s to the early 2000s as the birth span of the millennial demographic group. Millennials are generally the children of the older Baby Boomers and X-Gen generations. Millennials are sometimes referred to as "Echo Boomers", because of the 'boom' (large increase) in birth rates in the 1980s and 1990s. Fortunately in the 20th century, the trend toward smaller families in developed countries has continued to grow, so the relative impact of the "baby boom echoes" is generally not as great as from the post-World War II population.

The characteristics of millennials varies depends on the region and socio-economic conditions. However, this generation is generally characterised by their increased usage and familiarity with communications, media, and digital technology. In most parts of the world, their influence is characterised by increased political and economic liberalisation, although its influence is still debated. In Indonesia, millennials contribute to the high usage of communications, media, and digital technology, and rgis can be seen from more than $51 \%$ of the Indonesian population having become active Internet users. In addition, $69 \%$ of those users are using a mobile phone as their main activity support on a daily basis (GetCraft, 2018).

Generation Y, as a target market, presents certain challenges because they are resistant to traditional marketing efforts and are difficult to capture and maintain as loyal consumers (Bush et al., 2004; Wolburg and Pokrywczynski, 2001). They are very 
disloyal to the brand, and find it hard to continue repeat purchases (Sebor, 2006; Wood, 2004). This is unlike the $X$ generation of consumers who are very loyal and committed to the brand (Richie, 1995). Understanding the Y-generation approach to brands is a key branding strategy that targets this segment (Saxton, 2007). Generation $Y$ is the generation where brands must be very practical in their daily lives. This research study targets consumers in that age group because the researcher believes that the transportation service brand that they use is one that can spoil them. The Y generation is not concerned about price, because to them, comfort is beyond anything and comfort here also includes safety in driving.

\section{THEORETICAL BACKGROUND}

\section{A. Brand}

A brand is a label that implies an association, and it is a mirror of the promise made by the producer to the consumer for the quality of the product or service that has been produced. A great brand can function on more levels than the color and vibration of the product or service produced. The characteristics of a brand includes how many people are faithful to and still choose the brand. Some experts and marketing organisations have a different understanding of a brand. According to the Trademark Law no. 15 of 2001 article 1, paragraph 1, the notion of a mark is "a sign in the form of pictures, names, words, letters, numbers, color arrangements, or combinations of these elements which have differentiating power and are used in trade in goods or services". This definition is similar to the definition of the American Marketing Association version that emphasises on the role of brands as identifiers and differentatiors. Based on these two definitions, technically if a marketer creates a new name, logo, or symbol for a new product, then he has created a brand.

According to Kotler and Keller (2014: 460), the notion of a brand is "The name, the term, the sign, the symbol, the design, or any combination thereof, which is intended to identify the goods or services of a seller or group and distinguish them from competing products". Brands can have five meanings:

1. Attribute: Brand reminds the individual of certain attributes.

2. Benefits: The brand is not just a set of attributes, because the purchased consumer is also a benefit. 
3. Value: The brand declares something about the value of the manufacturer.

4. Culture: The brand represents its producer's culture.

5. Personality: The brand reflects a certain personality.

\section{B. Brand Awareness}

Brand Awareness is the ability of consumers to identify a brand under different conditions, which can be done with brand recognition. Brand awareness is created and enhanced by increasing brand familiarity through repeated exposure. This is so then the consumers feel familiar with the brand (Kotler and Keller, 2003; cited in Suciningtyas, 2012). Brand awareness is a key element in the brand equity generation as revealed by Villarejo, et al (2008; cited in Shahid et al, 2017). According to Shahid et al (2017), brand awareness is a primitive level of brand knowledge, involving at least the identification of the name of a brand or structure that has been developed through detailed information.

Shahid et al (2017) stated that brand awareness is the fundamental and foremost limitation in any brand-related search. It is the ability of a consumer to recognise and recall a brand in different situations. Brand awareness affects the decision-making of a consumer about a product. When a consumer is going to buy something, he considers a brand when he does so. If the consumer knows about his brand, he will provide more opportunities for buying and he will always make wise economic decisions. The most important goal of a company is building a strong brand, which not only affects shortterm revenues but it is also fruitful in the long term. Therefore, the goal of a good brand management team is to build a brand that lasts for decades and can add up more products (Kapferer, 2008; Keller et al, 2001).

\section{Brand Awareness has four levels (Aaker, 2009), as in Figure 1:}

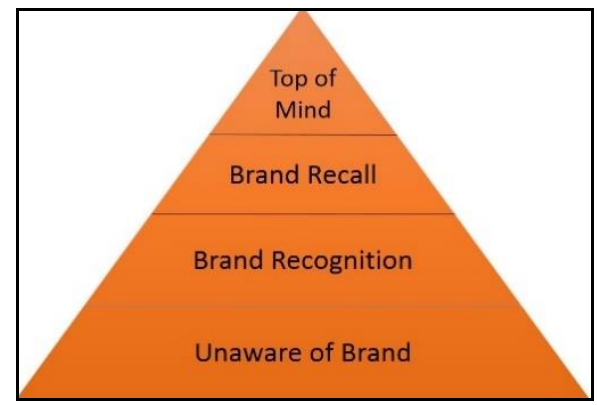

Source : Aaker (2009) 


\section{Figure 1 - Brand Awareness Piramyd}

1. Unaware brands are on the lowest level of the brand pyramid, where the consumers are unaware of a brand.

2. Brand recognition (brand recognition) is a minimal level of brand awareness where it is important when a buyer chooses a brand at the time of purchase.

3. Brand recall is a re-branding of the brand without any help because it is different from the introductory task.

4. Top of mind is the brand that is first remembered when the consumers are asked about the category of a product that can be spontaneously recalled without help.

The higher the level of brand awareness, the more remembered or in the minds of consumers that the brand is over others. Furthermore, brand awareness is not memory only. It is a learning process for the consumers, in relation to a brand. Building brand awareness is usually done over a long time, because memorisation can be successful with repetition and reinforcement. In fact, brands with a high level of reminder are often old brands. Consumers will tend to buy products from brands that they already know compared to products whose brands are still foreign to their ears.

\section{Purchase Intention}

Purchase intention is something that represents consumers who have the possibility, will, plan or who are willing to buy a product or service in the future. This increase in purchase intention means that there is an increased likelihood of purchase (Dodds Et Al, 1991; Schiffman and Kanuk, 2007). Researchers can also use buying intention as an important indicator for predicting consumer behaviour. When consumers have had the intention to buy, this form of commitment to a brand is positive and good. This is what drives the purchases that will ultimately be made by the consumers (Fishbein and Ajzen, 1975, Schiffman and Kanuk, 2007).

Purchase intention or buying interest, according to Assael (1998), is the tendency of consumers to buy a brand or to take action related to the purchase, measured by the level of possibility of the consumers to make a purchase. The notion of buying interest, according to Howard (1994), is something related to the consumer plan to buy a certain product, as well as how many units of a product is needed in a certain period. It can be 
said that buying interest is a mental statement from the consumers that reflects the purchase plan focused on certain products from a particular brand. This is needed by marketers for them to know the consumer buying interest in a product. Both marketers and economists use the variable of interest to predict consumer behaviour in the future.

\section{Framework}

\begin{tabular}{|c|}
\hline Brand \\
Awareness
\end{tabular} $\begin{aligned} & \text { Purchase } \\
& \text { Intention }\end{aligned}$

\section{METHOD, DATA AND ANALYSIS}

The data processing questionnaire was done by tabulating the answers to the respondent questionnaire. The answers were analysed using the average, standard deviation, frequency and crosstabulation to learn the size of the concentration and the diversity of the respondents.

\section{a. Operational Definition of the Variable}

1. The operational definition of the brand awareness variable was formed using the indicators developed by Aaker (2009). The operational defininition of brand awareness variable consist of four indicators (Aaker, 2009):

- Unaware brands

- Brand recall

- Brand recognition

- Top of mind

The operational definition of the purchase intention variable was formed using the indicators developed by Schiffman and Kanuk (2007). The operational defininition of the purchase intention variable consists of four indicators (Schiffman and Kanuk, 2007):

- Willingness to Use

- Possibility of Use

- Plan to Always Use

\section{b. Multiple Linear Regression Analysis}

Regression coefficient analysis is a test against the degree of significance of the relationship, and the magnitude of the influence of the independent variables 
(independent) on the dependent variable (dependent). This test can be done in two ways. First is with an F test used to determine the magnitude of the regression coefficient or test the level of significance of the two independent variables to the dependent variable. The second method is to see the partial regression coefficient that can be used to determine the level of influence of each independent variable to dependent variable.

The multiple linear regression analysis is a linear relationship between two or more independent variables $(\mathrm{X} 1, \mathrm{X} 2, \ldots . \mathrm{Xn})$ and the dependent variable $(\mathrm{Y})$. This analysis was conducted to know the direction of the relationship between the independent and dependent variable, whether each independent variable is positive or negative and to predict the value of the dependent variable if the value of the independent variable increases or decreases. The data used was sorted into scaled intervals or ratios. The multiple linear regression equation is as follows:

\section{$Y=a+b 1 X 1+b 2 X 2+b 3 X 3+b 4 X 4+e$}

Information:

$\mathrm{Y}=\mathrm{Re}$-buy intention

$\mathrm{X} 1=$ Price

$\mathrm{X} 2=$ Product Benefits

X3 = User of the Product

X4 = Product Class

b1 - b3 = Regression coefficient of promotional mix

$\mathrm{a}=$ Constants

$\varepsilon=$ Error

\section{c. Partial Significance Test (Test-t)}

A $\mathrm{T}$ test is a way to test whether the average of a population is equal to a certain price, or whether the average of two populations equals or differs significantly. The hypothesis testing of the regression coefficient was partially using a $t$ test. This test was done using a significant level of $0.05(\alpha=5 \%)$. Acceptance or rejection of hypotheses was done by the following criteria: 
1. If the significant value is $>0.05$, then the hypothesis is rejected (regression coefficient is not significant). This means that the partially independent variables have no significant effect on the dependent variable.

2. If the significant value is $\leq 0.05$, then the hypothesis is accepted (significant regression coefficient). This means that the partially independent variables have a significant effect on the dependent variable.

\section{RESULTS AND DISCUSSION}

In this study, the object was the $\mathrm{Y}$ generation, with an average age from 26 years old to 40 years old. The object was chosen because the age group contains consumers with comfort as their main concern when it comes to transportation services. From the questionnaires distributed, we obtained 119 respondents and 86.6 percent came from the age group of the $\mathrm{Y}$ generation.

1. Validity and reliability analysis

KMO and Bartlett's Test

\begin{tabular}{|c|c|c|}
\hline \multicolumn{2}{|c|}{ Kaiser-Meyer-Olkin Measure of Sampling Adequacy. } & .833 \\
\hline \multirow{3}{*}{$\begin{array}{l}\text { Bartlett's Test of } \\
\text { Sphericity }\end{array}$} & Approx. Chi-Square & 364.830 \\
\hline & df & 28 \\
\hline & Sig. & .000 \\
\hline
\end{tabular}

Reliability Statistics

\begin{tabular}{|r|r|}
\hline $\begin{array}{c}\text { Cronbach's } \\
\text { Alpha }\end{array}$ & N of Items \\
\hline .858 & 8 \\
\hline
\end{tabular}

Based on the results, it shows that the data has a high validity and reliability score. The validity score can be seen from the Keiser Meyer Olkin MSA score of 0.833 with a significance score of 0.000 . The reliability score can be seen from the Conbach Alpha score of 0.858 . This proves that the data making up the variable has a high level of validity and reliability. The data from the questionnaire can be used in the next analysis. 
2. The results of the simple linear regression analysis.

Model Summary

\begin{tabular}{|c|c|c|c|c|}
\hline Model & $\mathrm{R}$ & $\begin{array}{c}\mathrm{R} \\
\text { Square }\end{array}$ & $\begin{array}{c}\text { Adjusted } \\
\mathrm{R} \text { Square }\end{array}$ & $\begin{array}{c}\text { Std. Error of } \\
\text { the Estimate }\end{array}$ \\
\hline 1 & $.968 \mathrm{a}$ & .937 & .936 & 2.788 \\
\hline
\end{tabular}

a. Predictors: (Constant), Brand

Awareness

Based on the results of the above data, the $\mathrm{X}$ variable or brand awareness has a significant influence on the $\mathrm{Y}$ variable, or the intention to use Go-jek. The results show that the level of influence is $94 \%$. This proves that the brand of Go-Jek in Bandar Lampung city is very familiar in the minds of the people and has proven to be the main choice for the online public transportation in Bandar Lampung city. By comparing the average, this study proves that the online transportation brand Go-Jek is enjoyed by the milennial age group.

3. T Test

Coefficientsa

\begin{tabular}{|c|c|c|c|c|c|}
\hline \multirow{2}{*}{ Model } & \multicolumn{2}{|c|}{$\begin{array}{c}\text { Unstandardised } \\
\text { Coefficients }\end{array}$} & $\begin{array}{l}\text { Standardised } \\
\text { Coefficients }\end{array}$ & \multirow{2}{*}{$\mathrm{T}$} & \multirow{2}{*}{ Sig } \\
\hline & B & $\begin{array}{l}\text { Std. } \\
\text { Error }\end{array}$ & Beta & & \\
\hline (Constant) & 19.385 & .846 & & 4.918 & .000 \\
\hline $\begin{array}{l}\text { Brand } \\
\text { Awareness }\end{array}$ & 1.474 & .035 & .968 & 41.571 & .000 \\
\hline
\end{tabular}

a. Dependent Variable:

Purchase Intention 
Based on the results of the $t$ tests conducted, it can be concluded that the brand awareness obtained from the Go-jek has a positive effect on intention with an estimate score of 0.968 and more than $95 \%$ for the significance score. This explains that Go-Jek is an online transportation brand that highly influences people in Bandar Lampung to use its services. Bandar Lampung society believes in using Go-jek services, and that it will get them to the destination safely and comfortably. The underlying indicator is the good impression of the Go-Jek brand which is perceived by society, as the largest online tranportation brand.

\section{CONCLUSIONS}

The purpose of this study is to learn of the level of consumer purchasing intention in the above 26 year old age group (the Y Generation) in relation to using the online taxibike company, Go-Jek. The Generation Y age group was chosen because the age group has a close familiarity with using technology to support their daily activities. Brand awareness has more of a function than just giving the names and colours of the product or service produced. Brand awareness also deals with brand memories in the minds of consumers. Brand awareness is important for producers, as consumers will tend to buy products that are already known or remembered by them.

According to Surachman (2008), brand awareness is the ability of a potential buyer to recognise or recall that a brand is part of a particular product category. When consumers have had the intention to buy, it will form commitment to the brand, and that the brand is positive and good for the consumers. This is what drives the purchases that will ultimately be made by the consumers (Fishbein and Ajzen, 1975, Schiffman and Kanuk, 2007). The data processing was done by tabulating the respondent's answers drawn from the questionnaire.

Based on the analysis results, we obtained the result that $\mathrm{X}$ variable or brand awareness is a significant influence on the $\mathrm{Y}$ variable, or the customer's intention to buy GoJek services. Based on the results of the $t$ tests conducted, it can be concluded that brand awareness obtained from Go-Jek has a positive effect on intention with estimated score of 0.968 , and more than $95 \%$ for the significance score. This explains that Go-Jek is an online transportation brand that highly influences people in Bandar Lampung to use its services. 


\section{IMPLICATIONS}

1. The Go-Jek company should add an estimated time of arrival to their app so then consumers can estimate their time of arrival at the destination.

2. The Go-Jek company should make an innovation by adding in the option for the consumer to choose a vehicle that matches the consumer's size, so then the consumer will have a safe and comfortable journey with Go-Jek.

3. For the next research study, we can use a similar theme to this research but for another online taxibike company.

4. For the next research study, we can use adolescents and college students as the sampling population because they have a different response to online taxibike services.

\section{REFERENCES}

Aaker, D. (2009). Managing Brand Equity Management. Simon and Schuster.

Aminah, Siti. (2007). Public Transportation and Urban Society Accesibility. Politic Science Journal (Online).

Assael, H. (1998). Consumer Behaviour and Marketing Action, 6th edition. Cincinatti: South Western College Publishing.

Bush, A.J., Martin, C.A. and Bush, V.D. (2004). Sports celebrity influence on the behavioral intentions of Generation Y. Journal of Advertising Research, 44(1), pp. 108-118.

DFI. Yulianti. (2013). The Influence of Brand Image On Automotive Product Purchase Intention (Study On Toyota Avanza Buyer in Sutoyo-Malang Auto 2000 Dealer). The Economy and Business Journal of Malang Brawijaya University.

Dodds, W.B., Monroe K.B., Grewal, D. (1991) Effect of price, brand, and store information on buyers product evaluation. Journal of Marketing Research, 28(3), pp.307-319.

Fishbein, M., Ajzen, I. (1975). Belief, attitude, intentiton, and behavior: an introduction to theory and research. Addison-Wesley Publishing Company, MA. 1975

GetCraft. (2018). Indonesia's Digital And Content Marketing Report In 2017. Indonesia: GetCraft.com.

Howard, Alan D. (1994). A detachment-limited model of drainage basin evolution. Water Resources Research, 30(7), pp.2261-2286.

Kapferer, J.N. (2008). The New Strategic Brand Management: Creating and Sustaining Brand Equity.

Keller, K.L., Parameswaran, M.G. and Jacob, I. (2001). Strategic brand management: Building, measuring, and managing brand equity. Pearson Education India. 
Kotler, Philip and KL Keller. (2014). Marketing Management 14thed. New Jersey: Pearson Education.

Mahargiono, P. Bambang, and KE. Cahyono. (2017). The Online Transportation Controversy as the Base of Service Facility Settling For The Transportation Provider in Surabaya. Proceeding SENDI_U (2017).

Nadhilah, Siti. (2017). The phenomenon of Go-Jek Application Using On College Student in Bandung City. Library Diss.

Richie, L. (1995). Marketing to Generation X. Lexington Books: New York.

RY. Saputro, et al. (2016). "The Influence of Brand Awareness, Perceived Quality and Price Honda Vario 125 Motorcycle Buying Decision In Semarang Astra Honda Dealer. The Management and Economy Journal of Semarang Pandanaran University.

Saxton, G. (2007). Collections of Cool. Young Consumers: Insights and Ideas for Responsible Marketers, 6(2), pp. 18-27.

Schiffman, L.G., Kanuk, LL. (2007). Consumer Behaviour, 9thed. Prentice-Hall Inc, NJ.

Sebor, J. (2006). Y me. Customer Relationship Management, 10(11), pp. 24-27.

SLB. Silalahi, PW. Handayani, and Q. Munajat, "Service Quality Analysis for Online Transportation Services: Case Study of GO-JEK," 4th Information Systems International Conference 2017, ISICO 2017, 6-8 November 2017, Bali, Indonesia. 2017

Surachman SA. (2008). The Fundamentals of Brand Management. Malang : Bayumedia Publishing

T. Pindo, R. David, and E. Sonalitha. (2017). The Transformation of Conventional Taxibike to Online Taxibike. Journal of Management and Business Study, 3(1), pp.76-79.

Wolburg, J.M. and Pokrywczynski, J. (2001). A psychographic analysis of Generation Y college students. Journal of Advertising Research, 41(5), pp. 33-53.

Wood, L.M. (2004). Dimensions of brand purchasing behaviour: Consumers in the 1824 age group. Journal of Consumer Behaviour, 4(1), pp. 9-24.

Z. Shahid, T. Hussain and F. Azafar. (2017). The Impact of Brand Awareness on The consumers' Purchase Intention. Journal of Marketing and Consumer Research, ISSN 2422-8451, 33. 